\title{
Design, Synthesis and Antiviral Activity of 5-Hydroxymethyl-3-phosphonyl-4,5-dihydrofuran Analogs of Nucleotides
}

\author{
Hee-Yoon Lee, ${ }^{*}$ Kiho Lee, Jung Hwan Hah, Deuk Kyu Moon, and Chong-Kyo Lee ${ }^{\dagger}$ \\ Department of Chemistry, Korea Advanced Institute of Science and Technology, Daejeon 305-701, Korea \\ *E-mail:leehy@kaist.ac.kr \\ ${ }^{\dagger}$ Korea Research Institute of Chemical Technology Daejeon 305-600, Korea \\ Received May 25, 2010, Accepted June 14, 2010
}

Key Words: Antiviral, Nucleotide, Analog, Phosphonate

Phosphonate esters play an important role in studying the biological system as a hydrolytically stable replacement of phosphate groups ${ }^{1 \mathrm{a}}$ and as prodrugs of phosphonates. ${ }^{\mathrm{lb}}$ In continuation of our study on the chemistry of 1-alkenylphosphonates, ${ }^{4}$ we were interested in designing and developing versatile synthetic routes to conformationally constrained structures of alkenylphosphonate nucleotide analogs. ${ }^{1-3}$ After reporting a novel synthesis of spatially equivalent analogs of 1-alkenylphosphonates by introducing cyclopropane ring instead of olefin, ${ }^{5}$ we became interested in dihydrofuranyl phosphonate that would provide different constraint to the linker between phosphonate and the base. The dihydrofuran ring will serve as a rigid linker between purine/pyrimidine bases and phosphonyl groups of nucleotide inhibitors. A similar concept was introduced in a recent reports of dihydrofuryl nucleoside analogs that were shown to be anti-HCMV with resistance to enzymatic degradation, ${ }^{6}$ and tetrahydrofuryl phosphonate analogs of dideoxynucleosides. ${ }^{7}$ Though there have been many reports of synthesis of functionalized dihydrofurans, ${ }^{8}$ only few examples have been reported on the synthesis of phosphonyl derivatives ${ }^{9}$ with limited applicability to the preparation of various derivatives. While we were working on the synthesis of cyclopropyl phosphonates ${ }^{5}$ we encountered an unexpected formation of the phosphonyl dihydrofuran ring and this observation led us to develop a facile synthesis of functionalized dihydrofuranyl phosphonates. When 1-acyl-3-butenylphosphonate (1) was treated with $m$-CPBA with an anticipation of obtaining $\gamma, \delta$-epoxyphosphonate (2), 5-hydroxymethyl-3-phosphonyl-4,5-dihydrofuran (3), was obtained after basic work-up of the epoxidation reaction (Scheme 1). It appeared that the enolate was generated from the ketone under the basic condition and subsequent opening of the epoxide with the oxygen of the enolate produced the dihydrofuran ring during work-up.

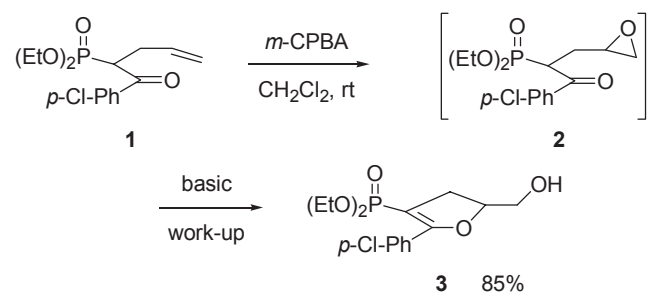

Scheme 1. One-pot epoxidation and cyclization
With the compound $\mathbf{3}$ in hand, nucleotide analogs were synthesized. The replacement of hydroxy group could be achieved either by direct coupling with a base unit, or by transformation to a leaving group with subsequent substitution reaction. ${ }^{10}$ In our system, direct Mitsunobu coupling reaction of hydroxy group was proven to be efficient with purine bases. The coupling reactions of $\mathbf{3}$ with 6-chloropurine and adenine under Mitsunobu reaction conditions afforded $\mathbf{4 a}$ and $\mathbf{4 b}$ in yields of $75 \%$ and $64 \%$, respectively (Scheme 2). While coupling reaction of 3 with 6-chloropurine underwent smoothly at $0{ }^{\circ} \mathrm{C}$, the synthesis of $4 \mathbf{b}$ required lower reaction temperature of $-10{ }^{\circ} \mathrm{C}$ to avoid the competing coupling of primary amine group. In case of pyrimidine, however, an indirect route was more fruitful, where the hydroxy group was activated as the mesylate, and then was replaced by cytosine (Scheme 2). Among the two nitrogen atoms in cytosine, the amino nitrogen did not react in this condition, and there occurred only the desired attack of aromatic $\mathrm{NH}$ group to give $4 \mathbf{c}$ in $87 \%$ yield. Unfortunately, direct hydrolysis ${ }^{7}$ of ethyl phosphonates 4a-c did not yield the desired phosphonate 6a-c. For the synthesis of 6a-c, ethyl phosphonate was replaced by benzyl phosphonate in four step sequence before the introduction of purine/pyrimidine, and hydrogenolysis
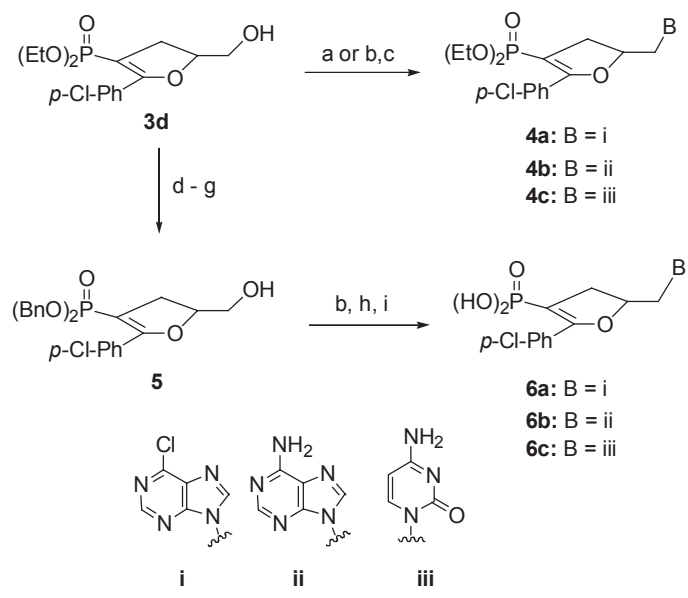

Reagents and conditions: (a) purines, $\mathrm{PPh}_{3}$, DEAD/THF, $75 \%$ for $\mathbf{4 a}, 64 \%$ for $\mathbf{4 b}$, (b) $\mathrm{MsCl}, \mathrm{Et}_{3} \mathrm{~N} / \mathrm{CH}_{2} \mathrm{Cl}_{2},-10{ }^{\circ} \mathrm{C}, 86 \%$, (c) cytosine, $\mathrm{Cs}_{2} \mathrm{CO}_{3} / \mathrm{DMF}, 70{ }^{\circ} \mathrm{C}, 87 \%$ (d) $\mathrm{BzCl}, \mathrm{Et}_{3} \mathrm{~N}, \mathrm{DMAP} / \mathrm{CH}_{2} \mathrm{Cl}_{2}, 88 \%$ (e) $\mathrm{TMSBr} / \mathrm{CH}_{2} \mathrm{Cl}_{2} ; \mathrm{MeOH}$ (f) $\mathrm{BnOH}, \mathrm{DCC} / \mathrm{PhH}$ (g) $\mathrm{K}_{2} \mathrm{CO}_{3} / \mathrm{MeOH}, 41 \%$ for three steps (i) nucleic base, $\mathrm{K}_{2} \mathrm{CO}_{3}, 18-\mathrm{C}-6 / \mathrm{DMF}$ (j) $10 \% \mathrm{Pd}-\mathrm{C} / \mathrm{MeOH}, 10 \%$ for $\mathbf{6 a}, 48 \%$ for $\mathbf{6 b}, 31 \%$ for $\mathbf{6 c}$, for three steps

Scheme 2. Synthesis of nucleotide analogs 
Table 1. Cytotoxicity and antiviral activity ${ }^{b}$

\begin{tabular}{cccc}
\hline & \multicolumn{3}{c}{ Hela299 Cell } \\
\cline { 2 - 4 } & $\begin{array}{c}\text { Cytotox. } \\
\mathrm{CC}_{50}{ }^{a}\end{array}$ & $\begin{array}{c}\text { HCMV AD-169 } \\
\mathrm{IC}_{50}{ }^{a}\end{array}$ & $\begin{array}{c}\text { HCMV Davis } \\
\text { IC }_{50}{ }^{a}\end{array}$ \\
\hline $\mathbf{4 a}$ & 76 & 56 & 56 \\
$\mathbf{4 b}$ & 12 & $>12$ & $>12$ \\
$\mathbf{4 c}$ & 155 & 129 & 139 \\
$\mathbf{6 a}$ & $>33.3$ & 12.7 & 13.5 \\
$\mathbf{6 b}$ & $>3.7$ & $>3.7$ & 3.0 \\
$\mathbf{6 c}$ & $>11.1$ & 4.8 & 6.1 \\
$\mathbf{G C V}$ & $>10$ & 5.8 & 0.7 \\
PFA & $>300$ & 90 & 112.8 \\
\hline
\end{tabular}

${ }^{a} \mu \mathrm{M},{ }^{b}$ standard CPE inhibition assay ${ }^{13}$ was used for antiviral test.

of the benzylphosphonate at the last step produced the desired phosphonates.

These compounds were tested for antiviral activity and the result was summarized in the Table 1. For the evaluation of antiviral activity, CoxB3 strains Nancy, EMCV strains EMC, VSV strains Indiana, HSV-1 strains F, HSV-2 strains MS, HIV-1 strains IIIB, HIV-2 strains ROD, HCMV AD-169 and HCMV Davis were used. HeLa299 cell was used for cytotoxicity assay. While cytotoxicity was observed from all the compounds tested, antiviral activity was observed only with HCMV strains at the concentration below the cytotoxic level. As anticipated, phosphonates $\mathbf{6 a}$ and $\mathbf{6 c}$ showed the antiviral activity at the concentration that was much lower than the cytotoxic concentration, and $\mathbf{6 b}$ showed antiviral activity near the cytotoxic level. This result was quite promising since the previous report on slightly different design of nucleoside phosphonates from Nair's group did not show antiviral activity. ${ }^{7}$ The activity might be related to the distance between phosphonate groups and purine/pyrimidine bases. When ethyl phosphonates were tested, those compounds also showed cytotoxicity and antiviral activity close to the cytotoxic level $(\mathbf{4 a}, \mathbf{4 c})$ or no antiviral activity below the cytotoxic level (4b). The fact that the antiviral activities of ethyl phosphonates (4a-c) were lower than that of phosphonates (6a-c) suggested that the ethyl phosphonates might be prodrugs of phosphonates that could be hydrolyzed under the test condition, or more likely, they showed weak antiviral activity through different mechanisms from the nucleotide antiviral compounds. ${ }^{12}$

In summary, we have designed and synthesized functionalized dihydrofurylphosphonates that are constrained analogs of 1-alkenyl-phosphonate derivatives of purine/pyrimidine nucleotides as they bear phosphonyl groups at the 3-position and bases at the methyl group of the 5-position of the furan ring. This newly designed dihydrofurylphosphonate analogs of nucleotide showed antiviral activity. Through the current synthetic strategy, structural diversification can be easily attainable for structure activity relationship study and for the better antiviral compounds.

Acknowledgments. This research was supported by a grant from Marine Biotechnology Project funded by Ministry of Land, Transportation and Maritime Affair, Republic of Korea.

\section{References}

1. (a) Du, Y.; Wiemer, D. F. J. Org. Chem. 2002, 67, 5701 and references therein. (b) Hecker, S. J.; Erion, M. D. J. Med. Chem. 2008, 51, 2328.

2. (a) De Clercq, E.; Holy, A.; Rosenberg, I.; Sakuma, T.; Balzarini, J.; Maudgal, P. C. Nature 1986, 323, 464. (b) Bronson, J. J.; Ghazzouli, I.; Hitchcock, M. J. M.; Webb, R. R., II.; Martin, J. C. J. Med. Chem. 1989, 32, 1457. (c) Balzarini, J.; Naesens, L.; Herdewijn, P.; Rosenberg, I.; Holy, A.; Pauwels, R.; Baba, M.; Johns, D. G.; De Clercq, E. Proc. Natl. Acad. Sci. USA 1989, 86, 332. (d) Adefovir dipivoxil - anti-HIV and anti-HBV. Drugs Future 2000, 25, 844. (e) Harnden, M. R.; Parkin, A.; Parratt, M. J.; Perkins, R. M. J. Med. Chem. 1993, 36, 1343. (f) Holy, A.; Votruba, I.; Masojidkova, M.; Andrei, G.; Snoeck, R.; Naesens, L.; De Clerq, E.; Balzarini, J. J. Med. Chem. 2002, 45, 1918.

3. (a) Piperno, A.; Chiacchio, M. A.; Iannazzo, D.; Romeo, R. Curr. Med. Chem. 2006, 13, 3675. (b) Armstrong, P. D.; Cannon, J. G.; Long, J. P. Nature 1971, 220, 56. (c) Spande, T. F.; Garaffo, H. M.; Edwards, M. W.; Yeh, H. J. C.; Pannell, L.; Daly, J. W. J. Am. Chem. Soc. 1992, 114, 3475. (d) McGroddy, K. A.; Carter, A. A; Tubbert, M. M.; Oswald, R. E. Biophys. J. 1993, 64, 325. (e) Chen, X.; Wiemer, A. J.; Hohl, R. J.; Wiemer, D. F. J. Org. Chem. 2002, 67, 9331. (f) Bubenick, M.; Rej, R.; Nguyen-Ba, N.; Attardo, G.; Ouellet, F.; Chan, L. Bioorg. Med. Chem. Lett. 2002, 12, 2063.

4. (a) Gil, J. M.; Hah, J. H.; Oh, D. Y. Tetrahedron Lett. 1998, 39 , 3205. (b) Gil, J. M.; Oh, D. Y. J. Org. Chem. 1999, 64, 2951.

5. Hah, J. H.; Gil, J. M.; Oh, D. Y. Tetrahedron Lett. 1999, 40, 8235.

6. Jeong, L. S.; Kim, H. O.; Moon, H. R.; Hong, J. H.; Yoo, S. J.; Choi, W. J.; Chun, M. W.; Lee, C.- K. J. Med. Chem. 2001, 44, 806.

7. Zheng, Y.; Nair, V. Tetrahedron 1999, 55, 11803.

8. (a) Ma, S.; Gao, W. Synlett 2002, 65. (b) Ichikawa, J.; Fujiwara, M.; Wada, Y.; Okauchi, T.; Minami, T. J. Chem. Soc. Chem. Commun. 2000, 1887. (c) Feldman, K. S.; Wrobleski, M. L. J. Org. Chem. 2000, 65, 8659. (d) Lee, Y. R.; Kim, B. S. Tetrahedron Lett. 1997, 38, 2095. (e) Alonso, I.; Carretero, J. C.; Garrido, J. L.; Magro, V.; Pedregal, C. J. Org. Chem. 1997, 62, 5682.

9. (a) Ruzziconi, R.; Gourves, H. C.; Gourves, J.-P.; Corbel, B. Synlett 2001, 703. (b) Pevzner, L. M.; Ignat'ev, V. M.; Ionin, B. I. Zh. Obshch. Kim. 1994, 64, 135 (Chem. Abstr. 1994, 121, 134268u). (c) Brel, V. K. Synthesis 1999, 463. (c) Qunter, A. A. Z.; Melman, A.; Srebnik, H. Synlett 2002, 61. (d) Lee, C.-W.; Oh, D. Y. Heterocycles 1996, 43, 1171.

10. (a) Chen, W.; Flavin, M. T.; Filler, R.; Xu, Z.-Q. J. Chem. Soc. Perkin Trans. 1 1998, 3979. (b) Yu, K.-L.; Bronson, J. J.; Yang, H.; Patick, A.; Brankovan, V.; Datema, R.; Hithcock, M. J. M.; Martin, J. C. J. Med. Chem. 1993, 36, 2726.

11. (a) Barchi, J. J., Jr.; Jeong, L. S.; Maqbool, M. A.; Marquez, V. E. J. Biochem. Biophys. Methods 1997, 34, 11. (b) Snoeck, R.; Sakuma, T.; De Clerq, E.; Rosenberg, I.; Holy, A. Antimicrob. Agents Chemther. 1988, 32, 1839. (c) Vero cells in stationary phase were infected with $100 \mu \mathrm{L}$ of the virus diluted with DME/2\% FBS to make $100 \mathrm{CCID}_{50}(50 \%$ cell culture inhibitory dose) per well of 96 -well plates. After 1 hour adsorption at $37^{\circ} \mathrm{C}$, the liquid was removed and $100 \mu \mathrm{L}$ of DME/2\% FBS containing a compound was applied to each well in duplicate for each concentration and further incubated for 3 days. Antiviral activity was measured by MTT assay. Antiviral activity was expressed as the $\mathrm{EC}_{50}$, or the concentration required to inhibit virus-induced CPD by $50 \%$. $\mathrm{EC}_{50}$ values were estimated from semilogarithmic graphic plots of the percentage of CPE as a function of the concentration of the test compound. Cytocidal assay was performed as a control experiment for antiviral assay. It was carried out simultaneously with the antiviral assay described previously using mock instead of virus for infection, and cell viability was measured by MTT assay. The concentration of compound responsible for $50 \%$ reduction of cell viability was calculated and expressed as $\mathrm{CC}_{50}(50 \%$ cytotoxic concentration)

12. Lee, Y.-S.; Kim, B. H. Bioorg. Med. Chem. Lett. 2002, 12, 1395. 